\title{
Evaluation of the inhibitory effect of dimethyl dicarbonate (DMDC) against wine microorganisms
}

\author{
A. Costa, A. Barata, M. Malfeito-Ferreira*, V. Loureiro \\ Laboratório de Microbiologia, Departamento de Botânica e Engenharia Biológica, Instituto Superior de Agronomia, \\ Technical University of Lisbon, 1349-017 Lisboa, Portugal
}

Received 10 May 2007; received in revised form 12 September 2007; accepted 1 October 2007

Available online 6 October 2007

\begin{abstract}
Several microbial species associated with wine were challenged against increasing concentrations of dimethyl dicarbonate (DMDC). The concentration inducing complete cell death upon addition to red wine was regarded as the minimum inhibitory concentration (MIC). In dry red wines with $12 \%(\mathrm{v} / \mathrm{v})$ ethanol and $\mathrm{pH} 3.50$, the inactivation depended on the initial cell concentration. For an initial inoculum of $500 \mathrm{CFU} / \mathrm{ml}$, the MIC of the yeasts species Schizosaccharomyces pombe, Dekkera bruxellensis, Saccharomyces cerevisiae and Pichia guilliermondii was $100 \mathrm{mg} / \mathrm{l}$. The most sensitive strains belong to Zygosaccharomyces bailii, Zygoascus hellenicus and Lachancea thermotolerans, with MIC of $25 \mathrm{mg} / 1$ DMDC. For inoculation rates of about $10^{6} \mathrm{CFU} / \mathrm{ml}$, the maximum dose of DMDC legally authorised $(200 \mathrm{mg} / \mathrm{l})$ was not effective against the most resistant species. The addition of $100 \mathrm{mg} / \mathrm{l}$ potassium metabisulphite (PMB), equivalent to $1 \mathrm{mg} / 1$ molecular sulphur dioxide, increased the inactivation effect of $100 \mathrm{mg} / 1$ DMDC over initial yeast populations of $10^{6} \mathrm{CFU} / \mathrm{ml}$ but did not fully kill $S$. pombe and $S$. cerevisiae.

Lactic acid and acetic acid bacteria were not killed by the addition of $300 \mathrm{mg} / \mathrm{l}$ of DMDC. Trials performed in wines before bottling showed that in most samples indigenous bacterial populations were not affected by $200 \mathrm{mg} / 1 \mathrm{DMDC}$. Therefore, under winery practice, DMDC at the maximum dose legally permitted may be regarded as an efficient preservative to control low contamination rates of yeasts but ineffective against lactic acid and acetic acid bacteria.
\end{abstract}

(C) 2007 Elsevier Ltd. All rights reserved.

Keywords: Wine; DMDC; Spoilage yeasts; Lactic acid and acetic acid bacteria; Dekkera/Brettanomyces bruxellensis; Cell death

\section{Introduction}

The microbiological stability of wines may be achieved by the use of chemical, physical and thermal treatments (Loureiro and Malfeito-Ferreira, 2003). The most common chemical preservative is sulphur dioxide but nowadays there is a trend to reduce its levels in wines. Another preservative is dimethyl dicarbonate (DMDC), authorised in the USA up to the cumulative amount of $200 \mathrm{ppm}$ (Anonymous, 2002) and in Australia up to $200 \mathrm{mg} / \mathrm{kg}$ (Anonymous, 2004). In Europe, DMDC has just been authorised with the maximum limit of $200 \mathrm{mg} / 1$ (Anonymous, 2006a). The effect of DMDC has been evaluated in

\footnotetext{
${ }^{*}$ Corresponding author. Tel.: + 351213653448 ; fax: + 351213653238

E-mail address: mmalfeito@isa.utl.pt (M. Malfeito-Ferreira).
}

wines against several yeast and bacterial species. Its efficiency depends on the strain, initial cell concentration, temperature, ethanol content and $\mathrm{pH}$ (Daudt and Ough, 1980; Ough et al., 1978, 1988; Porter and Ough, 1982; Threlfall and Morris, 2002). Appropriate usage of this product requires a dosing apparatus to ensure product homogenisation and consequent inactivation efficiency (Anonymous, 2006b). Although the efficiency of DMDC has already been studied, this work is justified by the recent authorisation of this product in Europe, where it may be added to wine with a sugar content of not less than $5 \mathrm{~g} / 1$ only a short time prior to bottling (Anonymous, 2006a). The purpose of this work was to provide an update of the knowledge of the action of DMDC against wine microorganisms in order to advise winemakers on its practical utilisation. 


\section{Material and methods}

\subsection{Yeast strains and maintenance conditions}

The yeast and bacterial strains used were obtained from culture collections or isolated in our laboratory (Table 1). Yeast strains were maintained on GYP slants $(20 \mathrm{~g} / 1$ glucose (Merck, Darmstadt, Germany), $5 \mathrm{~g} / 1$ yeast extract (Difco Laboratories, Detroit, USA), $10 \mathrm{~g} / 1$ peptone (Difco) and $20 \mathrm{~g} / 1$ agar, $\mathrm{pH}$ 6.0). Dekkera bruxellensis was kept in GYP plus $5 \mathrm{~g} / 1$ of calcium carbonate (Merck). Lactic acid bacteria were used as advised by the supplier (CHR Hansen, Hørsholm, Denmark). Acetic acid bacteria were maintained on GY slants (50 g/1 glucose (Merck), $10 \mathrm{~g} / 1$ yeast extract (Difco), and $13 \mathrm{~g} / 1$ agar, $\mathrm{pH} 4.5$ ), at $4{ }^{\circ} \mathrm{C}$.

\subsection{Effect of DMDC in wines}

A loopful of fresh yeast culture (24-48h) was used to inoculate $50 \mathrm{ml}$ of modified YNB broth $(6.7 \mathrm{~g} / 1 \mathrm{YNB}$ with amino-acids (Difco), $20 \mathrm{~g} / 1$ glucose, 10\% (v/v) ethanol), adjusted to $\mathrm{pH} 3.50 \pm 0.01$ and sterilised by filtration through membrane of $0.22 \mu \mathrm{m}$ pore size. Incubation was performed at $25^{\circ} \mathrm{C}$ with occasional hand shaking and growth was followed by measuring the absorbance at $640 \mathrm{~nm}$. When OD was about 0.5 units, diluted red wine with $2 \%(\mathrm{v} / \mathrm{v})$ ethanol was inoculated to give an initial

Table 1

Origin of analysed strains

\begin{tabular}{|c|c|c|}
\hline Species & Strains ISA ${ }^{\mathrm{a}}$ & Source $^{\mathrm{a}}$ \\
\hline Dekkera bruxellensis & ISA 1791 & Red wine \\
\hline Lachancea thermotolerans & 72 & $\begin{array}{l}\text { Fermenting grape juice, } \\
\text { UM } 72\end{array}$ \\
\hline \multirow[t]{3}{*}{ Pichia guilliermondii } & ISA 2105 & $\begin{array}{l}\text { Grapes (4-ethylphenol } \\
\text { producer) }\end{array}$ \\
\hline & ISA 2126 & $\begin{array}{l}\text { Press roll (4-ethylphenol } \\
\text { producer) }\end{array}$ \\
\hline & ISA 2131 & $\begin{array}{l}\text { Red wine (4-ethylphenol } \\
\text { producer) }\end{array}$ \\
\hline \multirow[t]{2}{*}{ Saccharomyces cerevisiae } & ISA 1000 & $\begin{array}{l}\text { Commercial starter } \\
(\text { Fermivin } \mathbb{B})\end{array}$ \\
\hline & ISA 1026 & Sediments in white wine \\
\hline Saccharomycodes ludwigii & ISA 1083 & $\begin{array}{l}\text { Sediments in sweet white } \\
\text { wine }\end{array}$ \\
\hline $\begin{array}{l}\text { Schizosaccharomyces } \\
\text { pombe }\end{array}$ & ISA 1190 & CECT 1375 \\
\hline \multirow[t]{2}{*}{ Zygosaccharomyces bailii } & ISA 1307 & $\begin{array}{l}\text { Valve in sparkling wine } \\
\text { production line }\end{array}$ \\
\hline & ISA 2270 & Sour rotten grapes \\
\hline Zygoascus hellenicus & ISA 2284 & Sour rotten grapes \\
\hline Oenococcus oeni & - & $\begin{array}{l}\text { Commercial starter } \\
\text { (Viniflora oenos }(\mathbb{R})\end{array}$ \\
\hline Acetic acid bacterium & - & $\begin{array}{l}\text { Catalase positive, gram- } \\
\text { rods isolated from red } \\
\text { wine }\end{array}$ \\
\hline
\end{tabular}

a ISA (Instituto Superior de Agronomia, Lisbon, Portugal), CECT (Colección Española de Cultivos Tipo, Madrid, Spain), UM (Minho University, Braga, Portugal). population of approximately $10^{4}$ cells $/ \mathrm{ml}$. A volume of $50 \mathrm{ml}$ of this diluted wine was poured into $100 \mathrm{ml}$ cotton plugged Erlenmeyer flasks. After cell inoculation, incubation was performed without shaking at $25^{\circ} \mathrm{C}$. Cells were counted with a counting chamber until approximately $10^{6}$ cells $/ \mathrm{ml}$. This wine mixture was then used to inoculate wine with $4 \%(\mathrm{v} / \mathrm{v})$ ethanol to a concentration of $10^{4}$ cells $/ \mathrm{ml}$. This procedure was repeated with wines of increasing ethanol concentration, namely $6,8,10$, and $12 \%(\mathrm{v} / \mathrm{v})$. Diluted wine was obtained by mixing with a solution of $5 \mathrm{~g} / 1$ tartaric acid to give the desired ethanol concentration.

Red wine blends were obtained by mixing several commercial red wines to which acetaldehyde was added in order to combine free sulphur dioxide. Glucose $(2 \mathrm{~g} / \mathrm{l})$ was added to wines with $12 \%$ (v/v) ethanol, $\mathrm{pH} 3.50$ and sterilised by filtration through $0.22 \mu \mathrm{m}$ pore membranes. $50 \mathrm{ml}$ were poured in $100 \mathrm{ml}$ Erlenmeyer flasks plugged with rubber stoppers and perforated by a hypodermic needle. Wines were inoculated with adapted cells to give an initial population of approximately $10^{4}$ cells $/ \mathrm{ml}$ and kept at $25^{\circ} \mathrm{C}$ without shaking. After $24 \mathrm{~h}$ of incubation, the above cultures were utilised to inoculate sterile experimental wines to give initial populations of $500 \mathrm{CFU} / \mathrm{ml}$ or $10^{5}-10^{6} \mathrm{CFU} / \mathrm{ml}$. Daily prepared ethanol (Merck) solutions of DMDC (Fluka) were added just after the cell inoculation and thoroughly mixed by hand to the desired concentrations $(25,50,100,150,200$ and $300 \mathrm{mg} / \mathrm{l})$.

After appropriate decimal dilution with Ringer solution, viability was measured by spread plating $0.1 \mathrm{ml}$ onto GYP, and grown from 3 to 5 days at $25^{\circ} \mathrm{C}$. At the end of each experiment leading to null viable countings, the remaining wine volume was analysed by membrane filtration $(0.22 \mu \mathrm{m}$ pore size), plated onto GYP, and incubated at $25^{\circ} \mathrm{C}$ for 3-5 days.

Results shown are the mean of two independent experiments, and averages did not vary by more than $10 \%$.

\subsection{Preparation of bacterial inocula}

Lactic acid bacteria (Viniflora Oenus $\mathbb{R}$ ) were prepared according to supplier's instructions by spreading the bacterial starter on the surface of $50 \mathrm{ml}$ wine in $100 \mathrm{ml}$ Erlenmeyer flasks and gently shaken. Red wine blends consisted of $4 \mathrm{~g} / 1$ malic acid (Merck), 12\% (v/v) ethanol, and $\mathrm{pH} 3.50$. Incubation was carried out for $24 \mathrm{~h}$ at $28^{\circ} \mathrm{C}$ without shaking, after which time experimental wines were inoculated to give an initial bacterial population of approximately 500 or $10^{6} \mathrm{CFU} / \mathrm{ml}$.

A loopful of fresh acetic acid bacteria was inoculated in $50 \mathrm{ml}$ of $60 \mathrm{~g} / 1 \mathrm{WLN}$ (Difco) in $100 \mathrm{ml}$ Erlenmeyer flasks, and kept at $28^{\circ} \mathrm{C}$ for $72 \mathrm{~h}$ without shaking. Experimental wines were prepared as described before for yeast experiments and inoculated to give an initial count of about 500 or $10^{6} \mathrm{CFU} / \mathrm{ml}$.

Wines inoculated with bacterial cultures were incubated at $28{ }^{\circ} \mathrm{C}$ without shaking. Viability of bacterial populations 
after addition of increasing concentrations of DMDC was assessed as described for yeast experiments.

\subsection{Effect of DMDC and potassium metabisulphite (PMB)}

In order to evaluate the effect of DMDC plus PMB, we selected four strains of the most resistant yeast species. Yeast strains were adapted to wine and inoculated in red wine blend $(12 \%(\mathrm{v} / \mathrm{v})$ ethanol, $\mathrm{pH} 3.50,2 \mathrm{~g} / \mathrm{l}$ glucose $)$ prepared as described before. After inoculation, $100 \mathrm{mg} / 1$ DMDC was added and immediately after PMB (Merck) solution to the desired concentration $(25,50$ and $100 \mathrm{mg} / \mathrm{l})$. Titration of free sulphur dioxide by the iodine method showed $15 \mathrm{mg} / 1$ free sulphur dioxide before PMB addition. PMB additions resulted in 20,30 and $51 \mathrm{mg} / 1$ of initial free sulphur dioxide, which correspond to $0.4,0.6$ and $1 \mathrm{mg} / 1$ of molecular sulphur dioxide, respectively (at $\mathrm{pH} 3.50$, the percentage of the molecular form is $2 \%$, according to Ribéreau-Gayon et al., 2006). Viability measurements were done as described before. When viable cells were not detected after $144 \mathrm{~h}$ of incubation, $20 \mathrm{ml}$ of wine were membrane filtered, plated onto GYP and colonies counted after 3 days at $25^{\circ} \mathrm{C}$. Other $20 \mathrm{ml}$ of wine were diluted with $80 \mathrm{ml}$ GYP broth in $200 \mathrm{ml}$ cotton plugged Erlenmeyer flasks, incubated at $25^{\circ} \mathrm{C}$ for $72 \mathrm{~h}$ to allow the recovery of damaged cells. These cells were evaluated by plating onto GYP.

\subsection{Effect of DMDC at the winery}

Trials were conducted at the winery on commercial red wines before bottling. Red wine stored in 15.4001 stainlesssteel vessels as well as red wine stored in new French oak barrels (2251) were tested. Samples $(100 \mathrm{ml})$ were taken from the vessels or from the barrels using sterile pipettes and transferred to Schott flasks. In order to measure the effects of DMDC, this product was added at a concentration of $200 \mathrm{mg} / 1$ to wine from tanks and $25 \mathrm{mg} / 1$ to wine from barrels. Samples with and without added DMDC were incubated, membrane filtered and colonies counted as described before.

\section{Results}

\subsection{Evaluation of DMDC tolerance}

The first inactivation trials were conducted in microplates $(200 \mu \mathrm{l})$ and test tubes $(2 \mathrm{ml})$ but were discarded because full cell inactivation was achieved with $25 \mathrm{mg} / 1$ of DMDC for all strains (results not shown). This indicated that low test volumes were not adequate to measure the killing effect of DMDC.

The viability variation of yeast populations in red wine after DMDC addition is shown in Fig. 1 for adapted cells of $D$. bruxellensis ISA 1791 under high inoculation rates and for two different test volumes $(50 \mathrm{ml}$ and 11$)$. For nonlethal doses of DMDC, the viability decreased during the

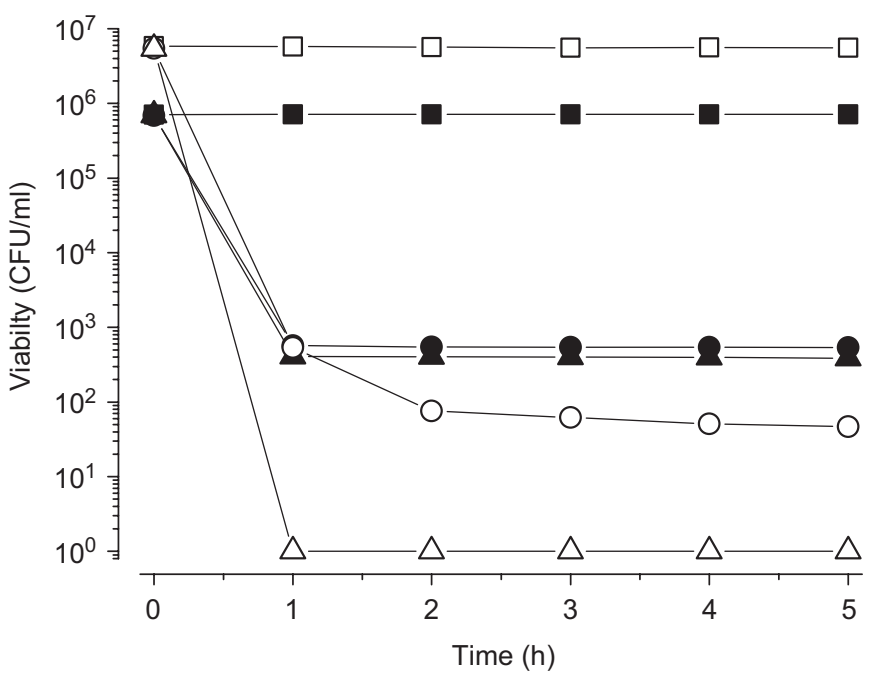

Fig. 1. Effect of DMDC on the viability of Dekkera bruxellensis ISA 1791 inoculated in $50 \mathrm{ml}$ (open symbols) and 11 (filled symbols) of red wine at pH 3.50 and $12 \%(\mathrm{v} / \mathrm{v})$ ethanol. DMDC concentrations: $0(\boldsymbol{\square}, \square), 200$ $(\bullet, \bigcirc)$ and $300 \mathrm{mg} / 1(\boldsymbol{\Lambda}, \triangle)$. The value $10^{\circ}$ for viability indicates the absence of colonies on the volume of $0.1 \mathrm{ml}$ of wine sample.

first $2-3 \mathrm{~h}$ and maintained constant afterwards. In 11 of wine the killing effect was lower demonstrating the importance of test volume standardisation to obtain reproducible results. The lower killing effect was also observed for Schizosaccharomyces pombe in 11 flasks (results not shown). We decided to use $50 \mathrm{ml}$ of wine because of laboratorial constraints when testing a high number of strains.

The behaviour pattern of the other yeasts strains tested during $5 \mathrm{~h}$ of incubation was similar to that displayed in Fig. 1 (results not shown). When DMDC doses induced total viability loss after $5 \mathrm{~h}$, death was checked after 72,144 and $216 \mathrm{~h}$ of incubation. This procedure enabled the determination of minimum inhibitory concentrations (MIC) necessary to achieve absence of viable counts. In Table 2 are shown the MIC values as a function of initial inoculation rate. For all strains the inactivation effect was dependent on the inoculum size, being the lowest MIC's obtained for inocula of $500 \mathrm{CFU} / \mathrm{ml}$. At high inoculation rates, $S$. pombe was the most resistant species, showing viability with $300 \mathrm{mg} / 1$ of DMDC (results not shown). Under low inoculation rates, $S$. pombe, $D$. bruxellensis, Saccharomyces cerevisiae and Pichia guilliermondii were found to be the most resistant yeast strains, maintaining viability with $50 \mathrm{mg} / \mathrm{l}$ of DMDC but not $100 \mathrm{mg} / 1$. The most sensitive strains were Zygosaccharomyces bailii, Zygoascus hellenicus and Lachancea thermotolerans, with MIC of $25 \mathrm{mg} / 1$ for inocula of $500 \mathrm{CFU} / \mathrm{ml}$.

The viability of lactic acid and acetic acid bacteria was not affected during the extent of the experiments for all tested concentrations of DMDC $(0-300 \mathrm{mg} / \mathrm{l})$ and therefore the MIC value was considered to be higher than $300 \mathrm{mg} / 1$. 


\subsection{Combined effect of DMDC and PMB}

The simultaneous effect of DMDC and PMB was determined using the four most resistant species. The viability results during incubation time are shown in Table 3. The addition of $100 \mathrm{mg} / 1$ of DMDC alone did not provoke viability loss during $144 \mathrm{~h}$ of incubation, as expected from the results presented in Table 2. However,

Table 2

Minimum inhibitory concentrations (MIC) of DMDC against wine associated microorganisms inoculated in red wine with $12 \%(\mathrm{v} / \mathrm{v})$ and $\mathrm{pH} 3.50$, at two different rates

\begin{tabular}{lll}
\hline Strains & \multicolumn{2}{l}{ DMDC (mg/l) } \\
\cline { 2 - 3 } & $500 \mathrm{CFU} / \mathrm{ml}$ & $10^{6} \mathrm{CFU} / \mathrm{ml}$ \\
\hline S. pombe ISA 1190 & 100 & $>300$ \\
D. bruxellensis ISA 1791 & 100 & 300 \\
S. cerevisiae ISA 1000 & 100 & 300 \\
S. cerevisiae ISA 1026 & 100 & 300 \\
P. guilliermondii ISA 2105 & 100 & 300 \\
P. guilliermondii ISA 2126 & 100 & 300 \\
P. guilliermondii ISA 2131 & 100 & 200 \\
$Z$. bailii ISA 1307 & 25 & 200 \\
$Z$. hellenicus ISA 2284 & 25 & 200 \\
S. ludwigii ISA 1083 & 25 & 200 \\
$Z$. bailii ISA 2270 & 25 & 150 \\
L. thermotolerans 72 & 25 & $>300$ \\
Oenococcus oeni & $>300$ & $>300$ \\
Acetic acid bacterium & $>300$ & \\
\hline
\end{tabular}

the addition of PMB induced different responses according to the strain. After $144 \mathrm{~h}$ of incubation, no viable cells were detected for $D$. bruxellensis and $S$. cerevisiae under $25 \mathrm{mg} / 1$ $\mathrm{PMB}$ and for $P$. guilliermondii under $50 \mathrm{mg} / 1 \mathrm{PMB}$. The most resistant species was $S$. pombe, tolerating $100 \mathrm{mg} / 1$ DMDC and $100 \mathrm{mg} / 1 \mathrm{PMB}$.

The absence of cell viability in the $0.1 \mathrm{ml}$ of wine does not exclude the presence of viable cells in higher wine volumes. Therefore we analysed $20 \mathrm{ml}$ wine by plating and another $20 \mathrm{ml}$ by incubation in resuscitation GYP broth. No viable cells were detected for $D$. bruxellensis and $P$. guilliermondii after membrane plating or inoculation in resuscitation broth. On the other hand, although $S$. cerevisiae did not show viability after membrane plating (non-culturable state), viable cells were recovered after broth culture. This indicates the presence of the so-called viable but non-culturable (VBNC) populations. Thus, for this latter species, the addition of $100 \mathrm{mg} / 1$ DMDC and $100 \mathrm{mg} / 1$ of PMB was not fully inhibitory.

\subsection{Effect of DMDC on indigenous microbial populations}

The effect of DMDC was tested under conditions adapted from winery practice. Table 4 shows the lethal effect of the maximum legal amount of DMDC (200 mg/l) on the indigenous microbial populations of red wine prepared to be bottled. In all samples, yeast counts were reduced to acceptable levels, mostly zero in $100 \mathrm{ml}$ of wine. On the contrary, bacterial counts were only reduced to zero

Table 3

Effect of $100 \mathrm{mg} / \mathrm{l} \mathrm{DMDC}$ and potassium metabissulphite (PMB) on the viability $(\mathrm{CFU} / \mathrm{ml})$ of several yeast strains inoculated in red wine with $12 \%$ (v/v) ethanol and $\mathrm{pH} 3.50$

\begin{tabular}{|c|c|c|c|c|c|}
\hline \multirow[t]{2}{*}{ Strains } & \multirow[t]{2}{*}{ Time (h) } & \multicolumn{4}{|l|}{ PMB (mg/l) } \\
\hline & & 0 & 25 & 50 & 100 \\
\hline D. bruxellensis ISA 1791 & $\begin{array}{r}5 \\
72 \\
144 \\
216^{\mathrm{a}} \\
216^{\mathrm{c}}\end{array}$ & $\begin{array}{l}9.7( \pm 0.2) \times 10^{5} \\
9.6( \pm 0.1) \times 10^{5} \\
9.5( \pm 0.1) \times 10^{5} \\
\mathrm{Nd}^{\mathrm{b}} \\
\mathrm{Nd}\end{array}$ & $\begin{array}{l}6.5( \pm 0.2) \times 10^{1} \\
<10 \\
<10 \\
0 \\
\text { Negative }\end{array}$ & $\begin{array}{l}1.8( \pm 0.1) \times 10^{1} \\
<10 \\
<10 \\
0 \\
\text { Negative }\end{array}$ & $\begin{array}{l}<10 \\
<10 \\
<10 \\
0 \\
\text { Negative }\end{array}$ \\
\hline P. guilliermondii ISA 2126 & $\begin{array}{r}5 \\
72 \\
144 \\
216^{\mathrm{a}} \\
216^{\mathrm{c}}\end{array}$ & $\begin{array}{l}2.6( \pm 0.1) \times 10^{5} \\
2.5( \pm 0.1) \times 10^{5} \\
2.6( \pm 0.2) \times 10^{5} \\
\mathrm{Nd} \\
\mathrm{Nd}\end{array}$ & $\begin{array}{l}2.0( \pm 0.1) \times 10^{2} \\
1.2( \pm 0.1) \times 10^{5} \\
1.6( \pm 0.1) \times 10^{5} \\
\mathrm{Nd} \\
\mathrm{Nd}\end{array}$ & $\begin{array}{l}6.1( \pm 0.1) \times 10^{1} \\
<10 \\
<10 \\
0 \\
\text { Negative }\end{array}$ & $\begin{array}{l}<10 \\
<10 \\
<10 \\
0 \\
\text { Negative }\end{array}$ \\
\hline S. cerevisiae ISA 1000 & $\begin{array}{r}5 \\
72 \\
144 \\
216^{\mathrm{a}} \\
216^{\mathrm{c}}\end{array}$ & $\begin{array}{l}9.6( \pm 0.2) \times 10^{5} \\
9.4( \pm 0.1) \times 10^{5} \\
9.5( \pm 0.1) \times 10^{5} \\
\mathrm{Nd} \\
\mathrm{Nd}\end{array}$ & $\begin{array}{l}5.9( \pm 0.1) \times 10^{2} \\
4.0( \pm 0.1) \times 10^{2} \\
<10 \\
0 \\
\text { Positive }\end{array}$ & $\begin{array}{l}5.6( \pm 0.2) \times 10^{2} \\
2.2( \pm 0.1) \times 10^{2} \\
<10 \\
0 \\
\text { Positive }\end{array}$ & $\begin{array}{l}1.8( \pm 0.2) \times 10^{2} \\
<10 \\
<10 \\
0 \\
\text { Positive }\end{array}$ \\
\hline S. pombe ISA 1190 & $\begin{array}{r}5 \\
72 \\
144\end{array}$ & $\begin{array}{l}6.7( \pm 0.2) \times 10^{5} \\
6.8( \pm 0.1) \times 10^{5} \\
6.8( \pm 0.2) \times 10^{5}\end{array}$ & $\begin{array}{l}2.0( \pm 0.1) \times 10^{2} \\
2.0( \pm 0.2) \times 10^{2} \\
6.3( \pm 0.2) \times 10^{3}\end{array}$ & $\begin{array}{l}2.6( \pm 0.2) \times 10^{3} \\
3.1( \pm 0.2) \times 10^{2} \\
4.0( \pm 0.1) \times 10^{3}\end{array}$ & $\begin{array}{l}2.7( \pm 0.1) \times 10^{3} \\
1.8( \pm 0.1) \times 10^{2} \\
9.8( \pm 0.1) \times 10^{2}\end{array}$ \\
\hline
\end{tabular}

${ }^{\mathrm{a}}$ Number of CFU after membrane filtration of $20 \mathrm{ml}$ of wine sample.

${ }^{\mathrm{b}}$ Not determined.

${ }^{\mathrm{c}}$ Negative or positive growth in $80 \mathrm{ml} \mathrm{GYP}$ broth added of $20 \mathrm{ml}$ of wine sample. 
Table 4

Range of microbial counts $(\mathrm{CFU} / 100 \mathrm{ml})$ before and after the addition of DMDC to finished red wine ${ }^{\mathrm{a}}$ prior to bottling

\begin{tabular}{|c|c|c|c|c|c|c|}
\hline \multirow[t]{3}{*}{ Number of samples } & \multicolumn{6}{|c|}{$\mathrm{DMDC}(\mathrm{mg} / \mathrm{l})$} \\
\hline & \multicolumn{3}{|l|}{0} & \multicolumn{3}{|l|}{200} \\
\hline & Yeasts & Bacteria & Moulds & Yeasts & Bacteria & Moulds \\
\hline 18 & $1-308$ & 0 & 0 & 0 & 0 & 0 \\
\hline 4 & $0-4$ & 9-TNTC & 1 & 0 & 0 & 0 \\
\hline 14 & $0-534$ & 17-TNTC & 0-TNTC & $0-3$ & 2-TNTC & 0-TNTC \\
\hline
\end{tabular}

${ }^{\mathrm{a}}$ Wine analysis range: free sulphite $26-58 \mathrm{mg} / \mathrm{l}$; $\mathrm{pH} 3.42-3.63$; ethanol $12.7-14.6 \%(\mathrm{v} / \mathrm{v})$.

${ }^{\mathrm{b}}$ Too numerous to count.

in four out of 18 contaminated samples. In 14 samples, bacterial populations were not affected by $200 \mathrm{mg} / 1$ DMDC. These results indicate that DMDC is not effective against bacteria.

To mimic cumulative additions of DMDC during storage in the winery, a separate trial was done in red wine matured in oak barrels. In five different samples initial yeast counts ranged from 16 to $146 \mathrm{CFU} / 100 \mathrm{ml}$. Utilisation of $25 \mathrm{mg} / 1$ of DMDC decreased counts to zero in four samples and to $1 \mathrm{CFU} / \mathrm{ml}$ in one sample, showing its effectiveness to keep wines with very low levels of yeast contamination.

\section{Discussion}

The first results on the effectiveness of DMDC against wine yeasts used $S$. cerevisiae at low inoculation rates (less than $100 \mathrm{CFU} / \mathrm{ml}$ ) and showed that less than $60 \mathrm{mg} / \mathrm{l}$ of DMDC were effective in avoiding visible growth in wine (Ough, 1975; Ough et al., 1978). Further work showed that variable initial populations $\left(17-10^{4} \mathrm{CFU} / \mathrm{ml}\right)$ of several strains belonging to $S$. cerevisiae, $S$. pombe, Brettanomyces spp., D. bruxellensis and Rhodotorula rubra were killed by $50-100 \mathrm{mg} / \mathrm{l}$ of DMDC after $48 \mathrm{~h}$, in $50 \mathrm{ml}$ wine with $10 \%$ (v/v) ethanol and $20 \mathrm{~g} / 1$ sugar (Daudt and Ough, 1980). Porter and Ough (1982) showed that $S$. cerevisiae was effectively killed by $100 \mathrm{mg} / 1 \mathrm{DMDC}$ within $10 \mathrm{~min}$ in $10 \%$ (v/v) wine with $20 \mathrm{~g} / 1$ sugar. The use of $25 \mathrm{mg} / 1$ free sulphur dioxide and $50 \mathrm{mg} / 1$ of DMDC were enough to control $S$. cerevisiae (inocula of $330-460 \mathrm{CFU} / \mathrm{ml}$ ) and avoid malolactic fermentation by Oenococcus oeni starters (Ough et al., 1988). Doses of $100 \mathrm{mg} / 1 \mathrm{DMDC}$ fully killed initial unadapted populations of 580-758 CFU $/ \mathrm{ml} \mathrm{S}$. cerevisiae var bayanus or prevented visible fermentations in wine with $11 \%(\mathrm{v} / \mathrm{v})$ and $12 \mathrm{~g} / 1$ sugar (Threlfall and Morris, 2002). These authors also showed that when $10 \mathrm{mg} / 1$ sulphur dioxide was added, $50 \mathrm{mg} / 1$ DMDC was enough to ensure wine stability. More recent publications have addressed grape juice treatments rather than wine (Delfini et al., 2002; Divol et al., 2005; Terrell et al., 1993). Thus, our results provided an update and a clarification of several aspects related with the killing effect of DMDC in wines, following its recent approval in the EU.
Using several contamination yeast species adapted to grow in wine with $12 \%(\mathrm{v} / \mathrm{v})$ ethanol and $\mathrm{pH} 3.50$ at $25^{\circ} \mathrm{C}$, we showed that the maximum legal dose $(200 \mathrm{mg} / \mathrm{l})$ of DMDC is an effective preservative when contamination loads are lower than $500 \mathrm{CFU} / \mathrm{ml}$. The inactivation effect of $200 \mathrm{mg} / \mathrm{l} \mathrm{DMDC}$ was also observed against indigenous yeast populations in commercial wine previous to bottling. For high microbial loads $\left(10^{6} \mathrm{CFU} / \mathrm{ml}\right)$ the effectiveness of DMDC depended on PMB addition. S. pombe and $S$. cerevisiae were particularly resistant, surviving under $100 \mathrm{mg} / 1 \mathrm{DMDC}$ and $1 \mathrm{mg} / 1 \mathrm{molecular}$ sulphur dioxide. This latter species seems survive due to the induction of a VBNC state, as has also been observed by Divol et al. (2005) in fermentations of botrytised juices.

Due to its rapid hydrolysis, the effect of DMDC is instantaneous and product suppliers advise the use of a dosing apparatus to ensure adequate homogenisation (Anonymous, 2006b). Our results showing that DMDC was much more effective in small test volumes (up to $2 \mathrm{ml}$ ) rather than larger ones $(50 \mathrm{ml}$ and 11$)$ may be explained by different volume dependent homogenisation. Perhaps the products of DMDC hydrolysis (Stafford and Ough, 1976) or the products of its reaction with alcohols and ammonia (Peterson and Ough, 1979) have a prolonged inhibitory effect. However, in winery practice, the prolonged preservation effect is mainly obtained by the presence of molecular sulphur dioxide. DMDC could therefore be used in regular additions during storage to decrease sulphur dioxide utilisation. Although this is common practice in USA, this procedure is not actually permitted by EU regulations.

Several reports showed that lactic acid bacteria in wines (Ough et al., 1988) or in juices (Delfini et al., 2002; Winniczuck and Parish, 1997) were more resistant to DMDC than yeasts. In this work we clearly establish that, in wines, DMDC under the authorised concentration limits is not an effective preservative against lactic acid and acetic acid bacteria. This lack of efficiency was observed for pure cultures as well as for indigenous populations before bottling. In conclusion, winemakers should regard DMDC as another hurdle for the prevention of yeast spoilage, being advisable to companies with the technological ability to maintain low microbial contamination levels in bottled wines. 


\section{Acknowledgements}

The research work was supported by FCT and by POCI 2010 (project POCI/AGR/56771/2004), shared by the European Fund FEDER.

\section{References}

Anonymous, 2002. Code of Federal Regulations, Title 27, vol. 1, revised as April 1, 2002. Cite 27CFR24.246, pp. 575-576.

Anonymous, 2004. Final Assessment Report, Application A474, Winemaking. Food Standards Australia New Zeland. 17 March 2004.

Anonymous, 2006a. Commission Regulation (EC) No 643/2006 of 27 April 2006. Official Journal of the European Union, 28.4.2006, L115/6-L115/9.

Anonymous, 2006b. Velcorin $\AA$. Product information leaflet. Lanxess Deutschland GmbH, Leverkusen, Germany.

Daudt, C.E., Ough, C.S., 1980. Action of dimethyldicarbonate on various yeasts. Am. J. Enol. Vitic. 31 (1), 21-23.

Delfini, C., Gaia, P., Schellino, R., Strano, M., Pagliara, A., Ambrò, S., 2002. Fermentability of grape must after inhibition with dimethyl dicarbonate (DMDC). J. Agric. Food Chem. 50, 5605-5611.

Divol, B., Strehaiano, P., Lounvaud-Funel, A., 2005. Effectiveness of dimethyldicarbonate to stop alcoholic fermentation in wine. Food Microbiol. 22, 169-178.

Loureiro, V., Malfeito-Ferreira, M., 2003. Spoilage yeasts in the wine industry. Int. J. Food Microbiol. 86, 23-50.

Ough, C.S., 1975. Dimethyldicarbonate as wine sterilant. Am. J. Enol. Vitic. 26 (3), 130-133.
Ough, C.S., Langbehn, L.L., Stafford, P.A., 1978. Influence of pH and ethanol on the effectiveness of dimethyl dicarbonate on controlling yeast growth in model wine systems. Am. J. Enol. Vitic. 29 (1), 60-62.

Ough, C.S., Kunkee, R.E., Vilas, M.R., Bordeu, E., Huang, M.C., 1988. The interaction of sulfur dioxide, $\mathrm{pH}$ and dimethyl dicarbonate on the growth of Saccharomyces cerevisiae Montrachet and Leuconostoc oenos MCW. Am. J. Enol. Vitic. 39 (4), 279-282.

Peterson, T.W., Ough, C.S., 1979. Dimethyldicarbonate reaction with higher alcohols. Am. J. Enol. Vitic. 30 (2), 119-123.

Porter, L.J., Ough, C.S., 1982. The effects of ethanol, temperature, and dimethyldicarbonate on viability of Saccharomyces cerevisiae Montrachet nr 522 in wine. Am. J. Enol. Vitic. 33 (4), 222-225.

Ribéreau-Gayon, P., Dubourdieu, D., Donèche, B., Lonvaud, A., 2006. Handbook of Enology. The Microbiology of Wine and Vinifications, vol. 1, second ed. Wiley, Chichester, England.

Stafford, P.A., Ough, C.S., 1976. Formation of methanol and ethyl methyl carbonate by dimethyl dicarbonate in wine and model solutions. Am. J. Enol. Vitic. 27 (1), 7-11.

Terrell, F., Morris, J., Johnson, M., Gbur, E., Makus, D., 1993. Yeast inhibition in grape juice containing sulphur dioxide, sorbic acid and dimethyldicarbonate. J. Food Sci. 58, 1132-1134.

Threlfall, R.T., Morris, J.R., 2002. Using dimethyldicarbonate to minimize sulfur dioxide for prevention of fermentation from excessive yeast contamination in juice and semi-sweet wine. J. Food Sci. 67 (7), 2758-2762.

Winniczuck, P.P., Parish, M.E., 1997. Minimum inhibitory concentrations of antimicrobials against micro-organisms related to citrus juices. Food Microbiol. 14, 373-381. 